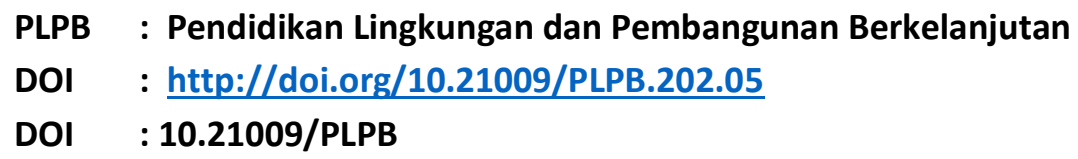

\title{
ADIWIYATA: Membangun Kepedulian dan Budaya LingkunganWarga Sekolah (Case study; SMPN 2 Gurah Kediri, Jawa Timur)
}

\author{
Nurul Jannah \\ Prodi Teknik dan Manajemen Lingkungan, Sekolah Vokasi Institut Pertanian Bogor \\ Jl. Kumbang No. 14, Cilibende - Bogor Tengah \\ Email: nurulipb@gmail.com
}

\begin{abstract}
Environmental education in schools is the application of education which includes knowledge, awareness and action. Environmental education applied by the Ministry of Environment and Forestry (KLHK) is the Adiwiyata Program. This program has the potential to raise school community awareness of the environment. This study aims to analyze the role of Adiwiyata in building environmental awareness and culture of school residents. This research uses descriptive qualitative methods and uses participatory data collection techniques, interviews and documentation. The results of the study showed that the Adiwiyata program contributed positively to school achievement in the environmental field. SMPN 2 Gurah, Kediri is a favorite school because it has a high concern, creativity and school innovation in the field of environment is very varied such as handmade batik with natural dyes, the development of local products such as passion fruit syrup, passion fruits and passion fruit preserves, and various waste recycling products to produce high economic value. Schools that are able to make good use of all available spaces, both indoors and outdoors for environmental learning while being able to involve the active participation of all school members will be better able to build schools that are environmentally friendly and cultured.
\end{abstract}

Keywords: Adiwiyata, peduli lingkungan, kreatifitas, inovasi, bidang lingkungan.

\begin{tabular}{|l|l|l|l|}
\hline Volume XX & Nomor 2 & September 2019 & e-ISSN : 2580-9199 \\
\hline
\end{tabular}




\section{PENDAHULUAN}

Kerusakan lingkungan hidup sebagian besar disebabkan oleh ulah manusia. Perilaku hidup manusia yang seenaknya dan tidak bertanggung jawab dalam mengeksploitasi lingkungan, mengindikasikan adanya masalah degradasi moral. Moral yang buruk mengakibatkan kondisi lingkungan hidup semakin kritis, dimana pada akhirnya dapat merugikan manusia itu sendiri. Untuk mengatasi dampak kerusakan lingkungan hidup diperlukan suatu perubahan sikap dan perilaku pada masyarakat serta perbaikan moral mendasar, salah satunya dapat dilakukan melalui penerapan pendidikan lingkungan hidup di sekolah.

Salah satu pendidikan lingkungan hidup yang diaplikasikan oleh pemerintah melalui Kementerian Lingkungan Hidup dan Kehutanan (KLHK) adalah Program Adiwiyata, program peduli dan budaya lingkungan. Program Adiwiyata diharapkan mampu menciptakan kondisi lingkungan yang nyaman, bersih, indah dan sehat sehingga dapat menambah semangat warga sekolah dalam menjalankan proses belajar-mengajar.

PermenLH No 5 tahun 2013 tentang Pedoman Adiwiyata menyebutkan bahwa Adiwiyata merupakan suatu tempat yang baik dan ideal untuk memperoleh segala ilmu pengetahuan dan berbagai norma serta etika yang dapat menjadi dasar manusia menuju terciptanya kesejahteraan hidup untuk mencapai cita-cita pembangunan berkelanjutan. Tujuan Adiwiyata adalah mewujudkan warga sekolah yang bertanggung jawab dalam upaya perlindungan dan pengelolaan lingkungan hidup melalui tata kelola sekolah yang baik untuk mendukung pembangunan berkelanjutan. Prinsip dasar program Adiwiyata adalah partisipatif dan berkelanjutan. Komunitas sekolah dalam prinsip partisipatif terlibat dalam manajemen sekolah yang meliputi keseluruhan proses perencanaan, pelaksanaan dan evaluasi sesuai tanggung jawab dan perannya. Prinsip berkelanjutan memiliki makna bahwa seluruh kegiatan harus dilakukan secara terencana dan terus menerus secara komprehensif, apabila sekolah memperoleh predikat sebagai sekolah Adiwiyata, maka harus bertanggung jawab dalam pengelolaan lingkungannya sekaligus mampu mewujudkan perilaku warga sekolah yang peduli dan berbudaya lingkungan.

Untuk memperoleh penghargaan sebagai sekolah Adiwiyata, sekolah harus memenuhi 4 komponen penting yang terdiri dari Pengembangan kebijakan sekolah yang berwawasan lingkungan, Pengembangan kurikulum berbasis lingkungan, Pengembangan kegiatan berbasis pertisipatif dan Pengembangan dan pengelolaan sarana pendukung sekolah yang ramah lingkungan. Program Adiwiyata bukan merupakan sebuah lomba, namun lebih menitikberatkan pada terbentuknya karakter dan perilaku warga sekolah yang peduli dan berbudaya lingkungan secara berkelanjutan. Dengan demikian, untuk mencapai penghargaan Adiwiyata diperlukan rangkaian perjuangan panjang, diawali dengan keberadaan komitmen yang kuat seluruh warga sekolah untuk mewujudkan sekolah peduli dan berbudaya lingkungan.

Keikutsertaan SMPN 2 Gurah dalam program Adiwiyata tentu juga memerlukan perjalanan yang tidak mudah. Berbagai kendala pun ditemui. Namun kendala-kendala yang ada dijadikan tantangan untuk bersama-sama menciptakan sekolah peduli dan berbudaya lingkungan. Kini, kebiasaan bersih-bersih, menanam pohon dan penghematan SDA sudah menjadi budaya sehari-hari yang diterapkan di SMPN 2 Gurah. Di bidang lingkungan, berturut-turut dari tahun 2014 SMPN 2 Gurah memperoleh predikat sebagai juara 1 lingkungan sekolah sehat tingkat Kabupaten, tahun 2015 Adiwiyata tingkat kabupaten, tahun 2016 Adiwiyata tingkat propinsi, terakhir tahun 2017, memperoleh predikat sebagai sekolah Adiwiyata tingkat nasional. Diharapkan 2 
tahun ke depan dapat meraih predikat sebagai sekolah Adiwiyata Mandiri, yang merupakan pencapaian tertinggi sebagai sekolah peduli dan berbudaya lingkungan.

Penelitian ini merupakan potret nyata bagaimana sekolah Adiwiyata mampu meningkatkan kepedulian seluruh warganya dalam berperilaku ramah lingkungan. Keikutsertaan sekolah dalam program Adiwiyata mampu menginspirasi seluruh warga sekolah untuk lebih peduli dan berbudaya lingkungan, di samping juga mampu mendorong dan memotivasi warga sekolah dalam meningkatkan prestasi dan inovasi-inovasi di bidang lingkungan.

\section{METODOLOGI}

Penelitian ini menggunakan metode deskriptif kualitatif dengan metode studi kasus di SMPN 2 Gurah Kediri Jawa Timur. Penelitian ini menggunakan metode deskriptif kualitatif untuk mendeskripsikan suatu fenomena yang terjadi. Penelitian dilakukan dengan mengamati situasi sosial yang ada di lapangan. Metode kualitatif digunakan untuk memahami dan menafsirkan makna suatu peristiwa interaksi tingkah laku manusia dalam situasi tertentu menurut perspektif peneliti.

Penelitian kualitatif dipilih untuk memahami obyek yang diteliti secara mendalam. Penelitian ini bertujuan untuk menganalisis peran Adiwiyata dalam membangun kepedulian dan budaya lingkungan warga sekolah. Data yang diambil bersumber dari data primer dan sekunder dengan teknik pengumpulan data secara partisipatif, wawancara, dan dokumentasi.

\section{HASIL DAN PEMBAHASAN}

\section{Pendidikan Lingkungan}

Pendidikan lingkungan merupakan suatu proses yang bertujuan membentuk perilaku, nilai dan kebiasaan untuk menghargai lingkungan hidup (Wirakusumah, 2010), selain itu pendidikan lingkungan hidup di sekolah merupakan salah satu penerapan pendidikan karakter yang meliputi pengetahuan (kognitif), kesadaran atau kemauan (afektif) serta tindakan (psikomotor).

Menurut Barlia (2008:7) secara khusus tujuan pendidikan lingkungan hidup adalah sebagai berikut:

a. Kesadaran (awareness) yaitu membantu anak didik mendapatkan kesadaran dan peka terhadap lingkungan hidup dan permasalahannya secara menyeluruh.

b. Pengetahuan (knowledge) yaitu membantu anak didik memperoleh dasardasar pemahaman tentang fungsi lingkungan hidup, interaksi manusia dengan lingkungannya.

c. Sikap (attitudes) yaitu membantu anak didik mendapatkan seperangkat nilainilai dan perasaan tanggung jawab terhadap lingkungan alam, serta motivasi dan komitmen untuk berpartisipasidalam mempertahankan dan mengembangkan lingkungan hidup.

d. Keterampilan (skills) yaitu membantu anak didik mendapatkan keterampilan mengidentifikasi, investigasi dan kontribusi terhadap pemecahan dan penanggulangan isu-isu dan masalah lingkungan.

e. Partisipasi (participation) yaitu membantu anak didik mendapatkan pengalaman, serta menggunakan pengetahuan dan keterampilan berpikirnya, untuk memecahkan dan menanggulangi isu-isu dan masalah lingkungan

Salah satu pendidikan lingkungan hidup yang diaplikasikan oleh pemerintah melalui Kementerian Lingkungan Hidup dan Kehutanan (KLHK) adalah Program Adiwiyata, program peduli dan budaya lingkungan. Program Adiwiyata diharapkan mampu menciptakan kondisi 
lingkungan yang nyaman, bersih, indah dan sehat sehingga dapat menambah semangat warga sekolah dalam menjalankan proses belajar-mengajar.

\section{Profil SMPN 2 Gurah, Kediri}

SMPN 2 Gurah terletak di Jalan Turus No 108 Kecamatan Gurah, Kabupaten Kediri Jawa Timur. Secara geografis SMPN 2 Gurah terletak di Kecamatan Gurah yaitu berada di $3 \mathrm{~km}$ sebelah Timur Monumen Simpang Lima Gumul yang merupakan ikon Kabupaten Kediri. SMPN 2 Gurah merupakan salah satu sekolah unggulan yang ada di Kabupaten Kediri. Meskipun terletak di pinggiran Kabupaten, namun jumlah siswa yang bersekolah disini sangat tinggi. Prestasi yang diraih oleh SMPN 2 Gurah cukup tinggi dan membanggakan apalagi untuk prestasi di bidang lingkungan. Prestasi di bidang lingkungan yang dicapai oleh SMPN 2 Gurah berturut-turut dari tahun 2014 adalah sebagai juara 1 lingkungan sekolah sehat kabupaten, tahun 2015 sebagai sekolah Adiwiyata tingkat kabupaten, tahun 2016 sebagai sekolah Adiwiyata tingkat propinsi, terakhir Desember tahun 2017 sebagai sekolah Adiwiyata tingkat nasional.

SMPN 2 Gurah merupakan sekolah negeri berbasis lingkungan yang memiliki networking luas, baik dengan pemerintah maupun swasta. Saat ini sekolah memiliki 916 siswa dengan 26 kelas rombel (rombongan belajar) dan memiliki 54 guru serta 17 tenaga kependidikan. SMPN 2 Gurah didirikan tahun 1990 dan memiliki luas lahan lebih dari satu hektar, $12.550 \mathrm{~m} 2$. Lahan yang luas tersebut oleh sekolah dimanfaatkan untuk gedung-gedung pembelajar, halaman sekolah, lapangan olah raga, lapangan upacara, tempat parkir dan sisanya dimanfaatkan untuk berbagai kegiatan lingkungan seperti taman, kebun, dan kolam. Fasilitas yang ada di sekolah unggulan tersebut berdampak pada kondisi dan keadaan lingkungan sekolah yang sejuk, rindang bersih dan nyaman.
Kreatifitas dan inovasi sekolah di bidang lingkungan sangat variatif seperti batik tulis dengan pewarna alami, pengembangan produk lokal seperti sirup markisa, asinan markisa dan manisan markisa. Selain itu, sekolah juga memiliki kreatifitas untuk memanfaatkan dan mengolah air bekas wudhu untuk kolam ikan, hemat energi, pembibitan plasma nutfah, hidroponik, Vertikal Garden, Biopori, green house, kolam ikan, hutan sekolah, tanaman buah, Tosa (Tanaman Obat Sekolah), serta berbagai produk daur ulang sampah hingga menghasilkan nilai ekonomi tinggi. Siswa-siswi SMPN 2 Gurah juga aktif mengikuti kegiatan KIR/Remaja Berprestasi. Prestasi demi prestasi terus ditorehkan oleh SMPN 2 Gurah ini.

\section{Perilaku Siswa}

Perilaku merupakan totalitas pemahaman dan aktivitas seseorang dimana merupakan hasil bersama antara faktor internal dan eksternal (Notoatmodjo, 2010). Faktor eksternal dalam bentuk sosial, budaya, ekonomi, dan politik, sedangkan faktor internal seperti perhatian, pengamatan, persepsi, motivasi, fantasi, dan sugesti.

Perilaku siswa dalam program Adiwiyata tercermin dalam 4 komponen penting yaitu:

\section{Pengembangan kebijakan sekolah yang berwawasan lingkungan}

Untuk mewujudkan sekolah peduli dan berbudaya lingkungan, sekolah diharapkan memiliki kebijakan-kebijakan yang berwawasan lingkungan. Kebijakan peduli dan berwawasan lingkungan SMPN 2 Gurah sudah dimasukkan dalam visi, misi, dan tujuan sekolah yang termaktub di dalam Kurikulum Tingkat Satuan Pendidikan (KTSP) sekolah. SMPN 2 Gurah memiliki visi "ber-Imtaq, berprestasi, terampil, berbudi luhur dan berbudaya lingkungan", dengan misi menerapkan perilaku sehat di lingkungan 
sekolah dan melaksanakan pelestarian dan penghijauan di lingkungan sekolah dan lingkungan sekitarnya. Visi misi yang dibangun oleh sekolah mampu menumbuhkan motivasi yang tinggi bagi warga sekolah untuk memiliki kepedulian dan budaya lingkungan yang baik sehingga mampu mengharmonisasikan alam, manusia, dan lingkungan demi terwujudnya proses pembelajaran yang nyaman dan menyenangkan. Selaras dengan visi misinya, SMPN 2 Gurah juga memiliki tujuan sekolah memelihara, mengelola dan melestarikan sumberdaya alam dan lingkungan sekitar melalui pembangunan karakter dan budaya lingkungan yang optimal.

Salah satu program stimulan yang diyakini mampu menjaga kebersihan dan kenyamanan lingkungan sekolah dalam proses belajar mengajar adalah diadakannya secara rutin lomba kebersihan kelas. Kegiatan ini merupakan ajang kompetisi sekaligus berfungsi sebagai media pembentukan karakter peserta didik, sehingga mendorong kepedulian lingkungan belajar yang menyenangkan sehingga mampu menumbuhkembangkan motivasi dan semangat berprestasi. Lomba kebersihan kelas ini benar-benar memotivasi warga kelas untuk bersamasama bertanggung jawab memelihara kebersihan kelas, sekaligus memotivasi kerjasama positif untuk meraih juara kelas terbersih.

Budaya cinta lingkungan yang dikembangkan di SMPN 2 Gurah antara lain berupa penerapan perilaku hidup sehat dan ramah lingkungan melalui pembiasaan perilaku ramah lingkungan seperti gerakan bersama menjaga kebersihan lingkungan, melaksanakan penghematan energi, memanfaatkan sumber daya alam yang ada disekitar sekolah serta melaksanakan pelestarian dan penghijauan di lingkungan sekolah dan lingkungan sekitarnya.

\begin{tabular}{rrr}
\multicolumn{2}{c}{ SMPN 2 Gurah memiliki } \\
kebijakan pengembangan materi
\end{tabular} lingkungan hidup yang tercantum dalam silabus, RPP, maupun lembar penilaian yang dirancang di awal tahun pelajaran. Untuk meningkatkan kualitas sumberdaya manusianya, sekolah secara reguler mengadakan workshop dan pelatihanpelatihan terkait dengan peningkatan kompetensi tenaga pengajar dan pendidik. Pemerintah Kabupaten Kediri melalui Dinas Lingkungan Hidup (DLH) Kabupaten sering mengundang sekolahsekolah di wilayah Kabupaten Kediri untuk mengikuti berbagai aktifitas kegiatan di bidang lingkungan seperti pelatihan, pameran, seminar, workshop maupun rapat-rapat kerja lainnya.

Tersedianya anggaran dana yang memadai juga sangat diperlukan oleh sekolah untuk mendukung pelaksanaan Program Adiwiyata secara berkelanjutan. SMPN 2 Gurah mengalokasikan sekitar 20 $\%$ dari anggaran kegiatan keseluruhan, untuk mendukung pelaksanaan kegiatankegiatan lingkungan. Hal ini telah diwujudkan sekolah dalam menentukan Rencana Kerja Anggaran Sekolah (RKAS). Agar dana yang dikeluarkan tidak mengalami defisit, SMPN 2 Gurah melakukan kebijakan penghematan terhadap sumberdaya alam yang digunakan seperti penghematan penggunaan air, listrik, energi, peralatan alat tulis kantor (ATK) serta berbagai keperluan kegiatan habis pakai lainnya.

\section{Pengembangan kurikulum berbasis lingkungan}

Dalam menyusun dan membuat Rencana Pelaksanan Pembelajaran (RPP), silabus maupun Kriteria Ketuntasan Minimal (KKM) semua mata pelajaran dipastikan sudah memasukkan dan mengintegrasikan materi tentang Lingkungan Hidup. Penyusunan dan pembuatan RPP meliputi RPP yang dilaksanakan di dalam kelas, di luar kelas, maupun di laboratorium. Sekolah juga harus menyusun dan membuat RPP yang memuat tentang isu lokal dan isu global 
yang sedang updated dibicarakan saat ini. Dalam menyusun dan membuat RPP, khusus untuk materi yang membahas lingkungan hidup diberikan highlight khusus, agar mudah untuk dicermati. Sebagaimana sekolah-sekolah lainnya, SMPN 2 Gurah juga menggunakan rujukan kurikulum tingkat satuan pendidikan (KTSP). Kurikulum tersebut mengintegrasikan lingkungan pada semua mata pelajaran. Dengan demikian semua mata pelajaran memiliki rencana pelaksanaan pembelajaran (RPP) yang dikaitkan dengan lingkungan, baik dari metode, model, pendekatan sampai media pembelajaran yang digunakan. Siswa akan merasa lebih bersemangat, rileks dan enjoy apabila berinteksi langsung dengan alam sekitar ketika proses pembelajaran menggunakan media alam. Siswa merasakan manfaat nyata apabila bisa belajar sekaligus bercengkerama langsung dengan alam sekitar.

Penanaman karakter peduli lingkungan pada siswa dilakukan secara integrasi, baik dalam bentuk praktik maupun teori. Dalam hal teori siswa dibekali dan disisipi materi yang berkaitan dengan lingkungan. Siswa diberi tugas yang berkaitan dengan lingkungan. Sementara untuk praktek pembiasaan diri, siswa diberi aktifitas yang berkaitan langsung dengan kecintaan dan kepedulian mereka terhadap lingkungan. Sebelum memulai pembelajaran, guru mengevaluasi kebersihan kelas dan meminta anak-anak ikut peduli terhadap kebersihan lingkungannya. Pada saat pembelajaran berlangsung, siswa juga selalu diingatkan untuk terus peduli lingkungan.

\section{Pengembangan kegiatan berbasis partisipatif}

Kerjasama sekolah dengan stakeholder terkait dalam mewujudkan sekolah Adiwiyata, sekolah peduli dn berbudaya lingkunngan; sangat baik dan saling mendukung. Hal ini dapat dilihat dari partisipasi mereka dalam berbagai kegiatan seperti penyuluhan kesehatan, sosialisasi lingkungan bersih, pemberian media tanaman, pemberian bibit (mulai bibit sayuran semusim hingga bibit tanaman tahunan), penyuluhan tentang remaja dan pengaruh narkoba dan masih banyak aktifitas positif lainnya.

Berbagai aktifitas dan kegiatan SMPN 2 Gurah selalu melibatkan siswa, baik kegiatan di dalam maupun di luar sekolah. Kegiatan pembiasaan diri di sekolah yang kemudian menjadi budaya sekolah dalam mencintai lingkungan; dilakukan melalui berbagai kegiatan seperti piket kebersihan kelas, jumat bersih, sabtu sehat serta operasi semut yang menjadi kegiatan rutin setiap pagi sebelum masuk kelas. Kegiatan lain adalah mengikutsertakan siswa dalam setiap lomba-lomba yang ada, khususnya terkait lingkungan. Mengikutsertakan siswa dalam aktifitas kegiatan lomba dapat menumbuhkan semangat dan motivasi yang tinggi kepada siswa untuk selalu peduli lingkungan. Lomba-lomba lingkungan yang rutin diikuti warga sekolah antara lain; lomba kebersihan kelas, lomba membuat puisi bertema lingkungan, lomba membuat yel-yel lingkungan, dan lomba menulis essay lingkungan serta lomba menggambar dengan tema lingkungan.

Berbagai jenis ekstrakurikuler yang dikembangkan di SMPN2 Gurah cukup banyak dan bervariasi seperti Karya Ilmiah Remaja (KIR), Palang Merah Remaja (PMR), pramuka, pecinta alam, majalah dinding dan poster, Batik Tulis, Paskibra, Seni Tari dan Teater. Kegiatan ekstrakurikuler yang dikembangkan di sekolah dimaksudkan tidak hanya sebagai wadah prestasi generasi muda SMPN 2 Gurah namun sekaligus untuk 
menumbuhkan kecintaan mereka kepada lingkungan. Untuk lebih menggugah partisipasi aktif siswa di lingkungan sekolahnya, SMPN 2 Gurah melibatkan siswa siswi dalam keanggotaan Kelompok Kerja (Pokja) lingkungan sekolah dengan berbagai tupoksi masing-masing. Terdapat lebih dari 10 Pokja lingkungan yang dikembangkan disini yaitu pokja kebersihan, pokja sampah, pokja biopori, pokja UKS, pokja taman sekolah, pokja satwa, pokja kolam, pokja green house, pokja toga. Keikutsertaan siswa dalam pokja sekolah merupakan suatu cara untuk membiasakan siswa bertanggung jawab dan berperilaku peduli serta ramah lingkungan. Sehingga dimanapun aktifitas dan kegiatannya, siswa terbiasa dengan perilaku peduli dan berbudaya lingkungan.

SMPN 2 Gurah juga menjalin kerjasama dan kemitraan dengan pihak luar, yaitu pemerintah dan swasta. Beberapa institusi pemerintah yang bekerjasama dengan sekolah antara lain Dinas Lingkungan Hidup (DLH), dinas kebersihan, dinas pendidikan, dinas kesehatan serta Badan Penanggulangan Narkoba. Kerjasama yang terjalin antara lain berupa bakti sosial, kebersihan wilayah tertentu, penghijauan, serta bakti lingkungan baik di dalam sekolah ataupun di luar sekolah.

Pelibatan aktif warga sekolah dalam setiap kebutuhan lingkungan nampaknya menjadi trend tersendiri bagi warga sekolah SMPN 2 Gurah. Banyaknya kegiatan sekolah yang melibatkan peran aktif siswa menumbuhkan sense of belonging yang kuat antara siswa dengan sekolah. Terdapat dua produk unggulan SMPN 2 Gurah yang secara ekonomi layak jual, bahkan kedua produk tersebut selanjutnya dijadikan ikon SMPN 2 Gurah, yaitu batik tulis dan aneka produk buah markisa.

Batik tulis yang dikembangkan oleh SMPN 2 Gurah menggunakan pewarna alami dengan memanfaatkan tanaman sekitar sebagai pewarna alami. Berbagai warna alami yang dikembangkan berasal dari pepohonan, mulai dari kunyit hingga buah mengkudu. Berbagai warna alami yang digunakan semuanya berasal dari tumbuhan yang ada di seputar sekolah dan wilayah sekitar sekolah. Berbagai warna alami yang dikembangkan antara lain kunyit (warna kuning), mangga (warna krem dan oranye), daun mangga (warna hijau), tumbuhan tom/indigo (warna biru), buah mengkudu (warna pink) dan pohon jati (warna merah/coklat).

Produk batik tulis yang asli berasal dari SMPN 2 Gurah menggunakan merek Guneda, yang artinya Gurah Negeri Dua. Batik Tulis Guneda sudah dikenal di kalangan Kediri karena memiliki ciri khas dan corak yang unik. Bahkan untuk mengembangkan kreatifitas warga sekolah, khususnya siswa, diberikan kesempatan untuk membuat sendiri corak, model dan warna batik yang akan digunakan oleh kelas masing-masing. Corak, model dan warna batik yang kemudian menjadi seragam kelas ini diperoleh dari hasil lomba design batik antar siswa di setiap kelas.

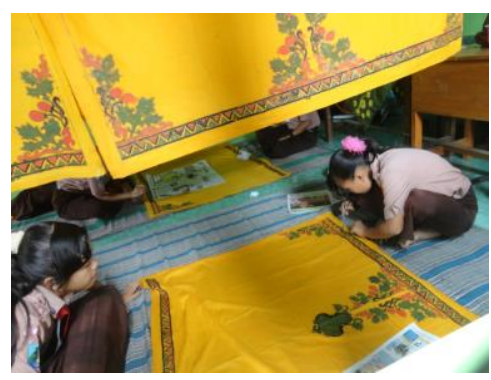

Gambar 1. Proses Pembuatan Batik Tulis oleh SMPN 2 Gurah

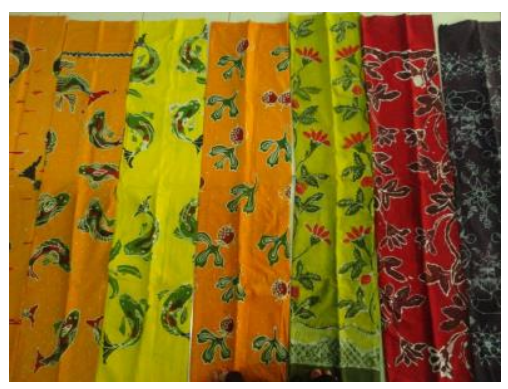

Gambar 2. Batik Tulis menggunakan pewarna alami produksi Guneda 


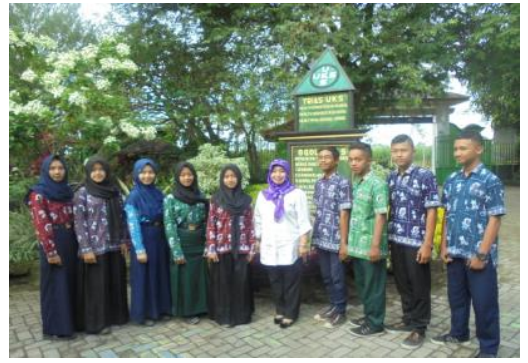

Gambar 3. Batik Kelas Buatan Siswa

Selain batik tulis, produk andalan SMPN 2 Gurah yang juga merupakan pengembangan produk lokal adalah aneka varian produk dari buah markisa. SMPN 2 Gurah telah berhasil memproduksi berbagai jenis minuman dan snack khas yang bahan dasarnya berasal dari buah markisa dikolaborasi dengan buah bligo. Produkproduk hasil kolaborasi antar markisa dan bligo tersebut sangat layak jual seperti manisan, juice markisa rasa ubi. Bahkan untuk kedepannya, SMPN 2 Gurah akan mengembangkan produk-produk lokal tersebut menjadi jajanan manisan berkuah "carica MARKISGO" yang bisa tahan lama walaupun tanpa bahan pengawet.

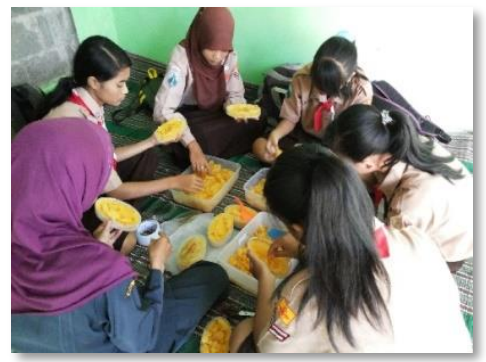

Gambar 4. Pengemasan manisan bligo rasa markisa

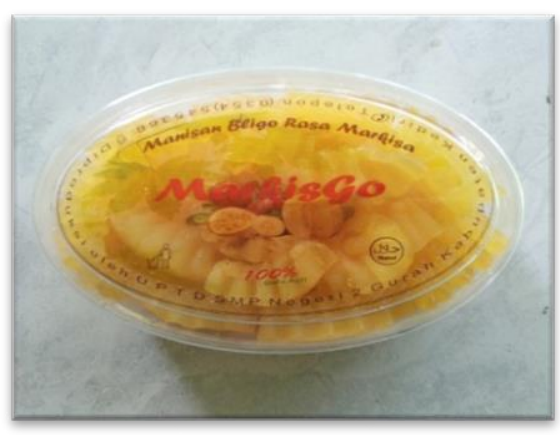

Gambar 5. Manisan bligo rasa markisa siap dihidangkan

\section{Pengembangan dan pengelolaan sarana pendukung sekolah berwawasan lingkungan.}

Sarana dan prasarana (sarpras) ramah lingkungan yang ada di SMPN 2 Gurah memiliki fungsi tidak saja untuk mengurangi permasalahan lingkungan yang ada, namun juga untuk pembelajaran siswa dalam menyelesaikan persoalan lingkungan. SMPN 2 Gurah memiliki banyak sarpras lingkungan, antara lain kantin ramah lingkungan, IPAL untuk memanfaatkan limbah air wudhu, taman kelas, taman hijau, Green House, School Garden, Gazebo tempat bermain dan belajar, serta budidaya berbagai satwa.

SMPN 2 Gurah memiliki kantin ramah lingkungan, yang bebas bahan plastik maupun stereofoam. Siswa dibiasakan untuk membawa sendiri tempat makan dan minuman, sehingga bisa dipakai kembali (reuse). Terkait dengan pengelolaan sampah di sekolah dikerjakan oleh siswa bekerjasama dengan mitra sekolah. Kegiatan pengelolaan sampah ini dimulai dari pengadaan mesin pencacah daun, pemilahan sampah, pembuatan lubang sampah organik hingga pembuatan mikro organisme lokal (MOL) untuk stater proses pengomposan. Produksi kompos/sampah organik sekolah digunakan untuk menyuburkan tanaman di lingkungan sekolah. Sedangkan sampah bekas anorganik, didaur ulang menjadi produk hasta karya siswa.

SMPN 2 Gurah menyediakan tempat sampah terpilah dalam tiga tempat yaitu tempat sampah warna hijau untuk sampah organik, tempat sampah warna kuning untuk sampah anorganik, serta tempat sampah merah untuk Bahan Berbahaya dan Beracun (B3) seperti zat-zat kimia yang digunakan untuk praktek, atau pembersih ruangan yang mengandung bahan kimia berbahaya. Sampah organik biasanya digunakan untuk kompos. 
Sampah anorganik didaur ulang menjadi produk kerajinan dan hasta karya siswa.

SMPN 2 Gurah juga memiliki warung hidup di bagian belakang sebagai implementasi kegiatan karya ilmiah remaja (KIR) yang membuat obat herbal serta makanan dari bahan apotik hidup. Selain apotik hidup lahan yang ada di sekolah juga digunakan untuk membuat taman sekolah. Hampir setiap gedung di SMPN 2 Gurah memiliki taman meskipun dalam skala kecil. Taman-taman yang dikembangkan di SMPN 2 Gurah ada di berbagai tempat dengan nama masing-masing seperti taman wakil kepala, taman toyota, taman kirai, taman therapi, taman BNI, green house, dan kebun pembibitan. Masing-masing taman tersebut terpelihara dengan baik sehingga dapat dimanfaatkan mulai dari tempat pembelajaran, rapat, kerja kelompok, hingga tempat refreshing siswa. Selain pepohonan rindang, di taman-taman SMPN 2 Gurah juga dikembangbiakkan burung-burung kecil yang terbang kesana kemari dengan suara khasnya yang riang dan nyaring. Taman-taman yang ada juga dilengkapi dengan air mancur dan kolam ikan.

Sarana dan prasarana yang ada di SMPN 2 Gurah apabila tidak dijaga dan dirawat dengan baik tentu akan mengalami kerusakan sehingga tidak bisa menjalankan fungsinya dengan baik. Untuk mengantisipasi agar sarpras yang ada tetap berfungsi dengan baik, SMPN 2 Gurah melakukan perawatan rutin serta penghematan sumberdaya seperti penghematan energi dengan menggunakan listrik seperlunya saja. Listrik dinyalakan bila kondisi gelap, TV, Komputer dimatikan apabila tidak digunakan, serta mematikan keran air bila air sudah penuh. Usaha penghematan lain berupa hemat air dengan menggunakan air seperlunya saja baik untuk wudhu maupun mencuci. Bak air dijaga jangan sampai airnya tumpah terbuang sia-sia. Penghematan kertas dilakukan dengan memanfaatkan kertas bekas untuk berbagai keperluan serta mengurangi dan menghindari pemakaian kertas yang berlebihan.

\section{KESIMPULAN}

Pendidikan lingkungan hidup lebih menekankan pada pengetahuan, tindakan serta kesadaran masyarakat tentang pentingnya pendidikan pembangunan berkelanjutan. Bentuk pembelajaran pendidikan lingkungan hidup tidak hanya berupa materi kurikulum, namun lebih kepada pembelajaran-pembelajaran dan praktek-praktek langsung yang berhubungan dengan alam secara nyata, sehingga pembelajaran yang diberikan kepada siswa akan lebih mudah diterima dan dipahami sehingga dapat mencapai sasaran yang diharapkan.

Mewujudkan warga sekolah menjadi lebih peduli dan berbudaya lingkungan memerlukan proses yang panjang, berkesinambungan dan terus menerus. Pencapaian SMPN 2 Gurah menuju sekolah Adiwiyata juga melalui proses panjang dan berkelanjutan. Selain itu, untuk mencapai predikat sebagai sekolah Adiwiyata, SMPN2 Gurah juga harus mampu memenuhi 4 komponen penting, yang meliputi pengembangan kebijakan sekolah peduli dan berbudaya lingkungan; pengembangan kurikulum berbasis linkungan; pengembangan kegiatan lingkungan berbasis partisipatif, serta pengembangan sarana prasarana ramah lingkungan. Melalui program Adiwiyata, pemerintah telah memberikan penghargaan tertinggi kepada sekolah-sekolah yang berhasil membangun karakter siswa menjadi individu yang bertanggung jawab dan peduli terhadap lingkungan hidup.

\section{REKOMENDASI}

Perilaku warga sekolah SMPN 2 Gurah yang peduli dan berbudaya lingkungan harus terus ditingkatkan. Perilaku tersebut diharapkan menjadi karakter siswa di manapun berada meskipun sudah lulus dari SMPN 2 Gurah. 
Diharapkan siswa yang telah menamatkan pendidikan di sekolah-sekolah yang berpredikat Adiwiyata dapat terus menjadi pelopor, pioneer bahkan agent of change sekolah karena memiliki kepedulian dan keberpihakan yang tinggi dalam bidang lingkungan hidup.

\section{DAFTAR PUSTAKA}

Barlia, Lily. 2008. Teori Pembelajaran Lingkungan Hidup di Sekolah Dasar. Subang: Royyan Press.

PermenLH No 5 Tahun 2013 tentang Pedoman Adiwiyata. 2013. Kementerian Lingkungan Hidup Republik Indonesia.

Panduan Adiwiyata Sekolah Peduli dan Berbudaya Lingkungan. 2011. Kerjasama Kementerian Lingkungan Hidup dengan Kementerian Pendidikan dan Kebudayaan.

Notoatmodjo, Soekidjo. 2010. Ilmu Perilaku Kesehatan. Jakarta: Rine

Wirakusumah. 2010. Konsep pendidikan lingkungan di sekolah: model uji coba sekolah berwawasan lingkungan. Bandung: FMIPA Universitas Pendidikan Indonesia. 
